\title{
INTEGRASI HUNIAN DALAM TOD UNTUK MENGATASI PERMASALAHAN TRANSIT KAWASAN PASAR LAMA, TANGERANG
}

\author{
Oscar Tanudjaja ${ }^{1}$, Felia Srinaga ${ }^{2}$, Alvar Mensana ${ }^{3}$ \\ 1,2,3. Jurusan Arsitektur, Fakultas Desain, Universitas Pelita Harapan, \\ Jl. M.H. Thamrin Boulevard 1100 Lippo Village, Tangerang \\ Email: otanudjaja@gmail.com
}

\begin{abstract}
Abstrak
Kawasan Pasar Lama merupakan kawasan yang sangat berkembang. Kawasan ini memiliki stasiun, yang dijadikan oleh banyak orang terutama dari daerah Tangerang dan Jakarta untuk singgah dan berbelanja. Selain itu, Stasiun Tangerang juga merupakan stasiun utama bagi komuter dari atau ke Jakarta. Karena itu, banyak masalah yang timbul terutama di titik utama kawasan, yaitu jalan utama dekat stasiun dan pasar. Permasalahan kemacetan lalu lintas dan pejalan kaki, maupun aktivitas pedagang dan penataan hunian di area ini menjadi perhatian utama yang perlu dibenahi dalam menciptakan ruang kota yang baik di kawasan ini. Salah satu solusi untuk mengatasi permasalahan tersebut adalah penerapan TOD (Transit Oriented Development). TOD merupakan pendekatan sistem transportasi yang berkelanjutan dilihat dari prinsip penyediaan aksesibilitas dan alternatif moda transportasi. Dengan adanya penerapan TOD di area transit stasiun, diharapkan keseluruhan kawasan Pasar Lama akan berkembang dan tercipta ruang kota yang baik di area ini. Penelitian ini bertujuan menjawab beberapa pertanyaan penelitian, yaitu: apa dan bagaimana penerapan prinsip TOD dengan mengintegrasikan hunian dalam TOD untuk menciptakan area transit kawasan Pasar Lama, Tangerang memiliki ruang kota yang baik. Penelitian ini dimulai dengan analisis konteks yang berlandaskan pada beberapa teori tentang urban dimension, human scale dan prinsip serta faktor keberhasilan sebuah TOD. Kemudian, dilanjutkan dengan melihat studi preseden dan observasi kawasan yang dijadikan sebagai referensi dalam menganalisis dan mengajukan konsep rancangan pada kawasan ini. Penelitian ini menghasilkan konsep rancangan penerapan TOD terutama pengembangan fungsi hunian, parkir, komersial dan ruang terbuka di kawasan Pasar Lama, Tangerang.
\end{abstract}

Kata kunci: TOD, transit, hunian.

\begin{abstract}
Title: Residential Integration in TOD to Overcome the Transit Problem in Pasar Lama Area, Tangerang

The Pasar Lama (Old Town Market) area is known as a highly developing area in the city of Tangerang. This area facilitated with a commuter train station used by people commuted from Tangerang to Jakarta in daily basis - both for transitting and shopping purposes. Tangerang Station is the main train station for commuters' from-and-to Jakarta; therefore, urban issues arise in the main urban nodes of the area, specifically the main boulevard near the station and the market. Issues such as transportation traffic, pedestrian congestion, informal street-vendors activities, and the arrangement of residential areas are major concern that needs to be addressed in the purpose of creating a good urban public space in the region. The solution to overcome this problem is to apply a concept for a TOD (Transit Oriented Development). TOD is a sustainable transportation system approach that provides accessibility and alternative modes of transportation. With the implementation of TOD in the transit station area, it is expected that the entire Pasar Lama area will be developed and created a good urban public space. This research study aims to answer several research questions, for instance: how does the concept of the TOD is able to integrate a residential program into the development and create a successful an urban public space as a transit area in the area of Pasar Lama, Tangerang. This research begins with context analysis based on several theories about urban dimension, human scale and key factors of a TOD. Precedent studies and observations on surrounding site, serve as references in analyzing and proposing draft concepts for this particular neighborhood. This research study will have an outcome in the form of design concept proposal that allow TOD to incorporate residential, parking, commercial, and open space as one district to revitalize the congested neighborhood in the Pasar Lama area, Tangerang.
\end{abstract}

Keywords: TOD, transit, residential. 


\section{Pendahuluan}

\section{Permasalahan Kawasan Pasar Lama}

Pasar lama adalah sebuah kawasan yang berlokasi di Jalan Kisamaun, kota Tangerang. Keberadaan kawasan ini terbentuk sejak lama yang dijadikan sebagai pusat perdagangan dan budaya tertua di kota Tangerang. Kawasan ini sangat kental dengan akulturasi budaya seperti Cina, Eropa, Betawi dan Sunda sehingga dijadikan kawasan cagar budaya. Kawasan ini memiliki dua titik utama yaitu area pasar tradisional dan area stasiun. Stasiun kereta pada kawasan ini juga memiliki peran yang penting karena merupakan stasiun utama dan berada di pusat kota Tangerang. Stasiun ini juga merupakan transit bagi para pekerja yang akan menuju ke Jakarta, sehingga banyak kendaraan pribadi yang diparkir di sekitar stasiun ini. Ramainya kawasan ini merupakan dampak langsung karena letak stasiun kereta yang berdekatan dengan pasar dan lokasinya yang berada di tengah kotaTangerang.

Ramainya kawasan ini hanya terjadi pada pagi dan malam hari, pada siang hari hanya ada pedagang yang mayoritas adalah pedagang dari kios-kios yang menjual kebutuhan sehari-hari dan alat elektronik. Banyak masalah yang timbul dari perkembangan yang terjadi terutama di titik - titik utama kawasan ini, antara lain berupa kemacetan yang dikarenakan tidak teraturnya penataan kawasan. Kemacetan yang terjadi juga disebabkan terbatasnya lahan parkir di area stasiun maupun pasar. Kemacetan ini ditambah dengan tingginya penggunaan kendaraan pribadi yang disebabkan sebagian besar hunian di Pasar Lama yang tidak memiliki akses langsung ke stasiun, dan terbatasnya sarana trasportasi publik yang menyebabkan kendaraan pribadi menjadi pilihan utama untuk berpergian. Tidak adanya akses langsung dari stasiun kereta menuju Pasar Lama juga membuat tidak nyamannya para pengunjung karena harus berjalan lebih dari 600-meter untuk menuju ke pasar dengan jalur pedestrian yang sempit dan tidak aman. Selain penataan jalur pedestrian, kawasan ini juga memerlukan penambahan ruang terbuka hijau di sekitar area stasiun dan pasar.

Dengan permasalahan-permasalahan tersebut, maka kawasan Pasar Lama membutuhkan pembangunan yang berorientasi ke pertumbuhan cerdas atau smart growth. Smart growth, menurut (Porter, 2002) adalah pertumbuhan yang menuntut pembangunan komunitas yang lebih ramah, produktif, dan bertanggung jawab secara budget dan lingkungan. Menurut Porter, ada 6 (enam) poin penting dalam smart growth yaitu, pengembangan yang ringkas namun multi guna, konservasi ruang terbuka, mobilitas yang diperluas, meningkatkan standar kehidupan, manajemen dan perluasan infrastruktur yang efisien, dan pembangunan secara adaptif di area yang akan dibangun. TOD (Transit Oriented Develoment) merupakan salah satu pendekatan yang digunakan untuk mencapai smart growth suatu kawasan. TOD adalah sebuah kawasan campuran yang berjarak 2.000 kaki dari terminal transit dan memiliki area komersial (Calthrope, 1993). Praktek TOD sudah populer diterapkan khususnya di kota-kota besar dunia.

Obyek penelitian adalah pengembangan pusat kawasan Pasar Lama untuk mengatasi permasalahan transit di area ini. Program ruang dan jenis hunian dalam TOD adalah hal yang diteliti dalam obyek penelitian ini. Hasil yang diharapkan dalam penelitian ini adalah ditemukannya program ruang dan jenis hunian yang tepat/sesuai dengan kriteria pengembangan area transit yang berorientasi pada transit-oriented development (TOD). Penelitian ini bertujuan untuk menjadikan area Pasar Lama sebagai pusat transit kota Tangerang yang bebas dari kemacetan, aksebilitas pejalan kaki yang tidak nyaman, hunian, dan ketidakteraturan kawasan, sehingga kawasan Pasar Lama dapat menjadi percontohan yang baik bagi pengembangan kawasan lain yang serupa. 


\section{Kajian Teori}

Transit merupakan kegiatan singgah sementara. Jika dimengerti dalam konteks transportasi kota, transit berarti berpindah melalui stasiun di dalam moda transportasi yang sama maupun yang berbeda. Kegiatan transit dapat menjadi potensi yang sangat baik dalam mendatangkan pengunjung yaitu dengan cara membuka akses menuju perhentian transit. Area transit dapat berada di dalam stasiun kereta, pelabuhan, terminal bus dan bandara. Area transit merupakan salah satu contoh ruang publik yang harus memiliki aksesibilitas dan konektivitas yang baik, memudahkan mobilitas untuk pejalan kaki maupun kendaraan, legibilitas ruang yang baik, memberikan kenyamanan bagi penggunanya, memiliki fungsi ruang dan aktivitas yang bermacam-macam dan mendukung adanya aktivitas sosial di dalamnya (Cho, 2016). Pada intinya, area transit adalah sebuah kawasan yang memungkinkan warganya berpidah moda tranportasi untuk perjalanan sehari-hari dengan nyaman. Area transit dapat diterapkan ke berbagai macam moda transportasi, salah satunya adalah penerapan pada stasiun kereta api.

Area transit stasiun kereta api merupakan prasarana kereta api sebagai tempat pemberangkatan dan pemberhentian kereta api untuk melayani kegiatan naik turun penumpang, bongkar muat barang, dan keperluan operasi kereta api seperti kesempatan untuk bersilangan dan bersusulan. Area transit dapat bertujuan untuk memudahkan pergantian moda transportasi dari kereta api ke moda lainnya dan sebaliknya. Pergantian moda akan membentuk nodes atau simpul kawasan dan memberi aliran aktivitas yang dinamis bagi kawasan. Area transit dalam stasiun kereta api adalah area yang dapat dikembangkan menjadi TOD (Transit Oriented Development).

TOD (Transit Oriented Development) merupakan pendekatan sistem transportasi yang berkelanjutan dilihat dari prinsip penyediaan aksesibilitas dan alternatif moda transportasi. Secara umum, TOD bertujuan untuk menciptakan lingkungan yang tidak bergantung terhadap kendaraan pribadi dan mendorong penggunaan transportasi publik seperti BRT (Bus Rapid Transit), MRT (Mass Rapid Transit), LRT (Light Rapid Transit), ataupun angkutan umum lainnya dan mempromosikan aksesibiltas yang baik untuk menuju ke titik - titik transit tersebut. Menurut ITDP (Institute for Transportation and Development Policy), kriteria dalam TOD adalah sebagai berikut:

\section{Connect}

Jalur pejalan kaki yang singkat dan langsung membutuhkan jaringan jalan-jalan yang padat di antara blok-blok kecil yang permeabel. Hal ini penting untuk kemudahan berjalan kaki dan aksesibilitas dari stasiun transit, karena dapat dengan mudah terdegradasi oleh rute yang memutar.

\section{Transit}

Angkutan umum menghubungkan dan mengintegrasikan wilayah-wilayah kota terlalu jauh bagi pejalan kaki. Akses dan kedekatan dengan layanan angkutan umum massal, yang didefinisikan sebagai Bus Rapid Transit (BRT) atau angkutan berbasis rel merupakan prasyarat untuk standar perancangan TOD. Angkutan umum massal memainkan peran penting, karena memungkinkan mobilitas perkotaan yang sangat efisien dan adil, serta mendukung tata ruang dan pola pembangunan yang padat.

\section{Mix}

Ketika ada percampuran yang seimbang antara peruntukan dan kegiatan dalam satu area misalnya, antara tempat tinggal, tempat kerja dan perdagangan ritel, akan banyak perjalanan sehari-hari yang berjarak dekat dan dapat ditempuh hanya dengan berjalan kaki. Perjalanan komuter pergi dan pulang juga dimungkinkan untuk lebih seimbang, sehingga operasional angkutan umum menjadi lebih efisien. Hunian berimbang, dari segi harga, memungkinkan para pekerja untuk tinggal di dekat tempat 
bekerja mereka dan mencegah Masyarakat Berpenghasilan Rendah (MBR) - yang paling tergantung pada angkutan berbiaya rendah - untuk tinggal di daerah-daerah terpencil dan malah mendorong kelompok ini untuk bergantung pada kendaraan pribadi.

\section{Densify}

Untuk dapat menopang pertumbuhan perkotaan dalam pola tata ruang yang rapat dan padat, kota harus tumbuh bukan secara horizontal tetapi secara padat dan vertikal. Kota dengan tingkat kepadatan yang tinggi dan berorientasi pada angkutan umum akan mendukung tersedianya layanan dengan kualitas, frekuensi, dan konektivitas yang juga tinggi sehingga akan membantu peningkatan pendapatan dengan investasi dalam perbaikan dan ekspansi sistem yang lebih baik. Kepadatan yang berorientasi pada angkutan umum akan menghasilkan jalan-jalan yang ramai, dan memastikan bahwa area stasiun tetap hidup, aktif dan aman. Kepadatan memberikan basis konsumen yang beragam bagi berbagai penyedia layanan dan fasilitas serta dapat menghidupkan aktivitas perekonomian lokal.

\section{Walk \& Cycle}

Berjalan kaki adalah moda transportasi yang paling alami, sehat, tanpa emisi dan terjangkau untuk jarak pendek, serta merupakan komponen penting dari suatu perjalanan dengan angkutan umum. Berjalan kaki merupakan dasar dari pengembangan sistem TOD yang merupakan cara yang paling menyenangkan dan produktif untuk berpergian. Hal ini dapat terjadi jika trotoar dan jalur pejalan kaki tersedia, ramai digunakan, serta terdapat media interaksi sosial dan elemen pendukung lainnya. Selain itu, bersepeda adalah opsi transportasi bebas emisi, sehat dan terjangkau, yang sangat efisien dan mengkonsumsi sedikit sekali ruang dan sumber daya perkotaan. Pengembangan TOD pada area transit merupakan salah satu contoh pengembangan ruang publik, sehingga kriteria di dalam TOD sebagian besar juga merupakan kriteria ruang publik yang baik. Oleh sebab itu, kriteria TOD yang ada dapat ditambahkan dan disempurnakan dengan kriteria ruang publik agar area TOD yang akan dikembangkan diharapkan menjadi lebih baik dan tetap memenuhi sebagian besar kriteria ruang publik berupa area transit yang baik (Cho, 2016).

Penggabungan kriteria TOD (ITDP, 1993) dan kriteria ruang publik adalah sebagai berikut:

1) Pada kriteria TOD Connect mencakup dua kriteria ruang publik yaitu akses dan konektivitas.

2) Pada kriteria TOD Transit mencakup kriteria ruang publik mobilitas.

3) Pada kriteria TOD Mix mencakup kriteria ruang publik yaitu variasi spasial.

4) Pada kriteria TOD Densify mencakup kriteria ruang publik yaitu legibilitas dan edges (tepian).

5) Pada kriteria TOD Walk and Cycle mencakup dua kriteria ruang publik yaitu aktivitas sosial dan kenyamanan di dalam jalur pejalan kaki dan sepeda.

Pada intinya, tujuan utama pengembangan TOD adalah membuat suatu kawasan menjadi kompak dimana segala hal yang dibutuhkan tersedia menjadi satu, menciptakan jalan dan pedestrian yang berorientasi kepada pejalan kaki dan pesepeda, mendorong penggunaan lahan di sekitar area transit dan hunian yang bervariasi. Pengembangan TOD diharapkan akan menjadikan suatu kawasan transit lebih ramah bagi pejalan kaki dan pesepeda, yang bertujuan untuk mendorong orang agar berpindah dari kendaraan pribadi ke transportasi umum.

Dalam pengembangan kawasan TOD, keberadaan hunian diperlukan untuk meningkatkan kepadatan area transit yang padat. Hunian merupakan salah satu fungsi ruang yang dapat diterapkan di TOD. Secara umum, hunian merupakan tempat tinggal atau kediaman. Menurut (Turner, 1972) dalam bukunya Freedom to Build, 
hunian adalah bagian yang utuh dari permukiman, dan bukan hasil fisik sekali jadi semata, melainkan merupakan suatu proses yang terus berkembang dan terkait dengan mobilitas sosial ekonomi penghuninya dalam suatu kurun waktu.

Dengan kepadatan dan keadaan sekitar kawasan transit dan komersial maka pengembangam hunian harus disesuaikan dengan kebutuhan yaitu berupa hunian dengan kepadatan tinggi dan bermacammacam jenis dan tipenya yang sesuai dengan kriteria pengembagnan kawasan TOD. Kriteria pengembangan hunian dalam TOD pada area transit adalah sebagai berikut:

Tabel 1. Kriteria (ITDP, 1993) (Cho, 2016), subkriteria dan parameter pengembangan hunian dengan TOD pada area transit

\begin{tabular}{|c|c|}
\hline $\begin{array}{c}\text { Kriteria \& subkriteria } \\
\text { pengembagan hunian dalam } \\
\text { TOD }\end{array}$ & Parameter \\
\hline $\begin{array}{l}\text { CONNECT } \\
\text { 1) Akses }\end{array}$ & \\
\hline $\begin{array}{l}\text { a) Akses pedestrian } \\
\text { b) Jarak tempuh dari moda } \\
\text { transportasi } \\
\text { c) Akses kendaraan }\end{array}$ & $\begin{array}{l}\text { a) Akses pedestrian } \\
\text { Lebar jalur pedestrian minimal } 4 \text { meter. } \\
\text { b) Jarak tempuh dari pemberhentian moda transportasi } \\
\text { Jarak tempuh adalah } 400-600 \text { meter. } \\
\text { c) Akses kendaraan } \\
\text { Minimal } 3 \text { akses menuju ke bangunan (akses pedestrian, } \\
\text { kendaraan, akses barang). }\end{array}$ \\
\hline Konektivitas & \\
\hline $\begin{array}{l}\text { a) Arah pergerakan } \\
\text { b) Konektivitas jalan } \\
\text { c) Konektivitas ground area }\end{array}$ & $\begin{array}{l}\text { a) Arah pergerakan } \\
\text { Jarak pergerakan ke pusat aktivitas } 400-600 \text { meter. } \\
\text { b) Konektivitas jalan } \\
\text { Banyaknya persimpangan, panjang satu blok berkisar 100-200 } \\
\text { meter. } \\
\text { c) Konektivitas ground area dengan bangunan } \\
\text { Jalan raya, pedestrian dan bangunan yang saling berhubungan } \\
\text { secara aktivitas maupun visual. }\end{array}$ \\
\hline $\begin{array}{l}\text { MIX } \\
\text { 3) Variasi spasial }\end{array}$ & \\
\hline $\begin{array}{l}\text { a) Keanekragaman ruang } \\
\text { aktivitas } \\
\text { b) Keanekaragaman ruang } \\
\text { bangunan } \\
\text { c) Kapasitas hunian } \\
\text { d) Variasi hunian }\end{array}$ & $\begin{array}{l}\text { a) Keanekragaman ruang aktivitas } \\
\text { Variasi aktivitas beragam (lebih dari } 1 \text { aktivitas dapat berupa } \\
\text { retail, kantor, hunian, RTH). } \\
\text { b) Keanekaragaman ruang bangunan } \\
\text { Berada dalam radius } 600 \text {-meter dari stasiun atau halte terdekat. } \\
\text { c) Kapasitas hunian } \\
\text { Kapasitas harus memenuhi kepadatan minimal } 400 \\
\text { penduduk / ha. } \\
\text { d) Variasi hunian } \\
\text { Variasi tipe, bentuk, dan klasifikasi hunian. } \\
\text { Penyediaan hunian terjangkau minimal } 20 \% \text {. }\end{array}$ \\
\hline $\begin{array}{l}\text { TRANSIT } \\
\text { 4) Mobilitas }\end{array}$ & \\
\hline $\begin{array}{l}\text { a) Ramah pesepeda } \\
\text { b) Perpindahan moda } \\
\text { transportasi } \\
\text { c) Tata guna lahan parkir } \\
\text { d) Titik drop off }\end{array}$ & $\begin{array}{l}\text { a) Ramah pesepeda } \\
\text { Lebar jalur sepeda minimal } 2 \text { meter. } \\
\text { Parkir sepeda yang cukup. } \\
\text { b) Perpindahan moda transportasi } \\
\text { Maksimal 600-meter dari area transit. } \\
\text { Minimal } 2 \text { moda transportasi. } \\
\text { c) Tata guna lahan parkir } \\
\text { Luasan gedung parkir } 10 \% \text { dari luas total bangunan. } \\
\text { Rasio jumlah parkir rekomendasi 1:100-meter luasan. } \\
\text { d) Titik drop off }\end{array}$ \\
\hline
\end{tabular}




\begin{tabular}{|c|c|c|}
\hline & & $\begin{array}{l}\text { Titik drop yang memadai dan tidak menimbulkan masalah } \\
\text { kemacetan. }\end{array}$ \\
\hline \multicolumn{3}{|l|}{$\begin{array}{l}\text { DENSIFY } \\
\text { 5) Legibilitas \& batasan }\end{array}$} \\
\hline $\begin{array}{l}\text { a) Pusat aktivitas } \\
\text { b) Permeabilitas } \\
\text { c) Variasi ketinggian dan } \\
\text { fungsi bangunan } \\
\text { d) Tata guna ruang dan lahan }\end{array}$ & $\begin{array}{l}\text { a) } \\
\text { b) } \\
\text { c) }\end{array}$ & $\begin{array}{l}\text { Pusat aktivitas } \\
\text { Akses ke dalam bangunan yang mudah. } \\
\text { Permeabilitas } \\
\text { Jumlah akses masuk bangunan minimal } 3 \text { per 100-meter } \\
\text { bangunan. } \\
\text { Variasi ketinggian dan fungsi bangunan } \\
\text { Memiliki beberapa variasi ketinggian dan fungsi dalam } \\
\text { bangunan. } \\
\text { Tata guna ruang dan lahan } \\
\text { Tata ruang dirancang se-efisien mungkin dengan kepadatan } \\
\text { minimal } 400 \text { orang / ha. }\end{array}$ \\
\hline \multicolumn{3}{|l|}{$\begin{array}{l}\text { WALK \& CYCLE } \\
\text { 6) Aktivitas sosial }\end{array}$} \\
\hline $\begin{array}{l}\text { a) Jalur pejalan kaki dan } \\
\text { sepeda } \\
\text { b) Infrastruktur pejalan } \\
\text { kaki dan sepeda } \\
\text { c) Nodes (simpul) }\end{array}$ & a) & $\begin{array}{l}\text { Jalur pejalan kaki dan sepeda } \\
\text { Jalur pejalan kaki minimal } 4 \text { meter. } \\
\text { Jalur sepeda minimal } 2 \text { meter. } \\
\text { Infrastruktur pejalan kaki dan sepeda } \\
\text { Penerangan jalur dan tempat parkir sepeda. } \\
\text { Adanya tempat duduk, tempat sampah. } \\
\text { Nodes (simpul) } \\
\text { Adanya beberapa titik penting sebagai penanda suatu kawasan }\end{array}$ \\
\hline \multicolumn{3}{|l|}{ 7) Kenyamanan } \\
\hline $\begin{array}{l}\text { a) Kenyamanan dan } \\
\text { penghawaan jalur pejalan } \\
\text { kaki dan sepeda }\end{array}$ & a) & $\begin{array}{l}\text { Kenyamanan dan penghawaan jalur pejalan kaki dan sepeda } \\
\text { Adanya peneduhan berupa kanopi lebar minimal } 1,5 \text { meter di } \\
\text { sepanjang jalur. } \\
\text { Adanya pepohonan yang rindang di sepanjang jalur, adanya } \\
\text { RTH yang luas. } \\
\text { Suhu yang nyaman. }\end{array}$ \\
\hline
\end{tabular}

Sumber: Analisis pribadi

\section{Analisis Site}

Obyek penelitian yang diambil oleh peneliti adalah kawasan stasiun Tangerang dengan pertimbangan permasalahan pada area stasiun ini yang memenuhi sebagian besar perlunya kawasan dikembangkan sesuai dengan kriteria pengembangan sebuah TOD.

Area stasiun juga memiliki banyak akses dan merupakan pintu utama menuju ke Pasar Lama, sehingga dengan adanya pengembangan area stasiun dapat secara langsung membantu perkembangan keseluruhan kawasan Pasar Lama.

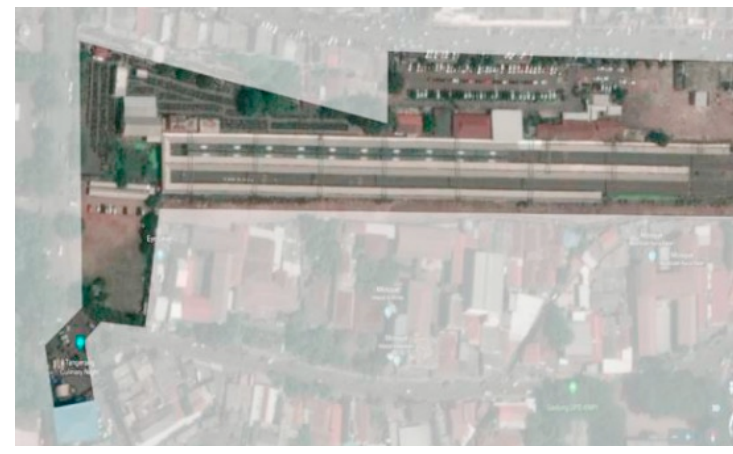

Gambar 1. Site Stasiun Tangerang yang terpilih Sumber: Google Earth, diolah peneliti

Analisis ini dijabarkan berdasarkan kriteria dan subkriteria yang ada (lihat tabel 1).

\section{Akses}

Stasiun Tangerang memiliki akses yang cukup banyak. Untuk mencapai ke Stasiun Tangerang dapat diakses dengan berjalan 
kaki, dengan kendaran pribadi (dapat berupa mobil atau motor), dengan angkutan kota (angkot) dan kereta komuter dari arah Kota Jakarta.

Akses pejalan kaki: Akses pejalan kaki berupa jalur pedestrian yang berada di sisi kiri dan kanan Jalan Kiasnawi. Namun, pedestrian yang ada hanya selebar 1.5meter dan terhalang oleh barang - barang dagangan di depan pertokoan. Akses jalan, dan fasilitas pesepeda juga tidak tersedia di sepanjang jalur menuju ke stasiun.

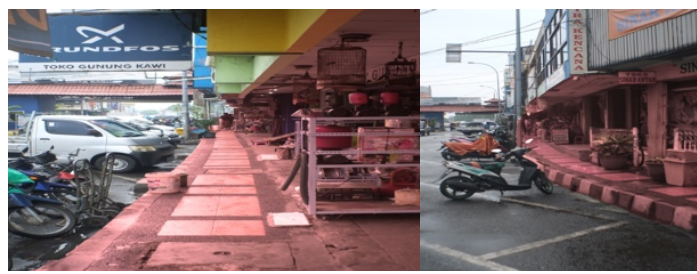

Gambar 2. Kondisi pedestrian

Sumber: Dokumentasi pribadi, 2019

Akses kendaraan bermotor: Selain berjalan kaki, stasiun dapat diakses dengan motor, mobil, taksi dan angkutan kota melalui Jalan Kisamaun, Jalan Daan Mogot dan jalan kecil atau gang (lebar jalan rata - rata sekitar empat meter) di sekitar Jalan Kiasnawi.

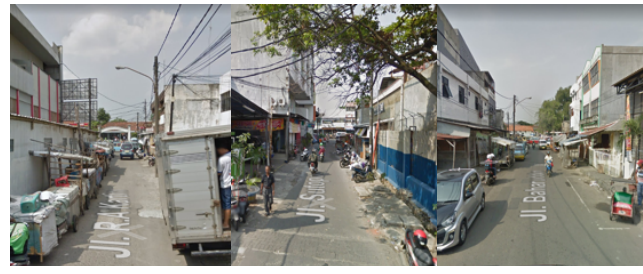

Gambar 3. Kondisi jalan sekitar stasiun Sumber: Dokumentasi pribadi, 2019

Akses kereta komuter: Stasiun ini melayani kereta komuter dengan headway 5 menit sehingga menjadikan stasiun ini ramai terutama pada jam pergi dan pulang kerja.

\section{Konektivitas}

Area stasiun memiliki konektivitas langsung ke Jalan Raya Kiasnawi, tetapi untuk menuju ke pusat aktivitas (area pasar) yang berada di Jalan Kisamaun, membutuhkan waktu lebih dari 10 menit berjalan kaki melalui jalur pedestrian dengan kondisi yang tidak nyaman.

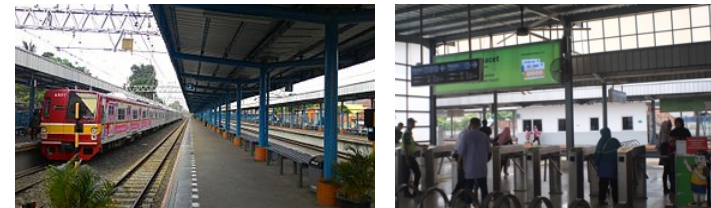

Gambar 4. Kondisi peron dan Stasiun Tangerang Sumber: Dokumentasi pribadi, 2019

Selain itu, akses kendaraan dari pusat aktivitas (Pasar Lama) juga semakin jauh dan harus melalui jalan Kiasnawi karena area drop off kendaraan di Stasiun Tangerang dipindah ke Jalan Kiasnawi. Konektivitas ground area dengan bangunan terlihat bahwa kondisi pedestrian yang ada walaupun sempit, namun banyak aktivitas di dalamnya membuat area pedestrian menjadi hidup. Jalan raya, pedestrian dan bangunan saling terkoneksi secara langsung.

\section{Variasi Spasial}

Keanekaragaman aktivitas: Kawasan ini memiliki beragam ruang spasial untuk melakukan aktivitas. Keanekaragaman aktivitas di area stasiun adalah:

Kegiatan transit dimana para pekerja memarkirkan kendaraan pribadi (motor atau mobil) di area parkir stasiun dan melanjutkan perjalanan dengan kereta komuter ke kota Jakarta dan sebaliknya. Sedangkan kegiatan perdagangan berada di sekitar stasiun yang terdiri dari toko - toko elektronik yang tersebar di pinggir Jalan Kiasnawi dan area hunian yang berada di belakang area pertokoan Jalan Kiasnawi dan sekitar Stasiun Tangerang.

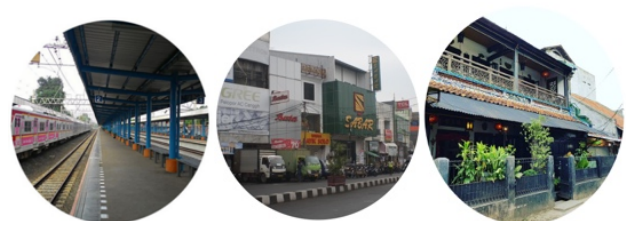

Gambar 5. Kegiatan transit, area komersial pertokoan dan hunian

Sumber: Dokumentasi pribadi, 2019

Keanekaragaman hunian dan kepadatan wilayah: Keanekaragaman hunian di kawasan ini tidak beragam. Keseluruhan hunian di kawasan Pasar Lama berupa rumah tapak yang memiliki ketinggian satu hingga tiga lantai. Jumlah penduduk di 
wilayah ini adalah 4.810 orang dengan kepadatan wilayah mencapai 5.010 orang per $\mathrm{km}$ persegi. Dengan kepadatan 5.010 orang per $\mathrm{km}^{2}$ atau 50 orang per hectare, maka wilayah ini termasuk ke dalam kepadatan sedang, jauh di bawah standar kepadatan tinggi yang mencapai 400 orang per hectare/40.000 orang per $\mathrm{km}^{2}$ yang direkomendasikan pada wilayah transit.

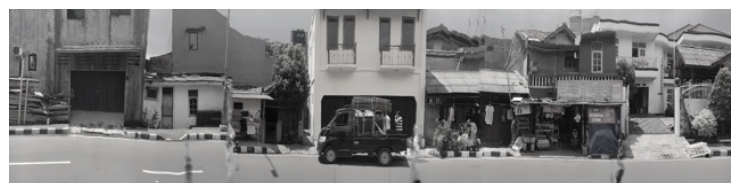

Gambar 6. Tipologi hunian berupa hunian tapak Sumber: Dokumentasi pribadi, 2019

\section{Mobilitas}

Perpindahan moda transpotasi dan area drop off: Perpindahan moda pada area stasiun Tangerang terlihat cukup mudah antara kendaraan pribadi atau kendaraan umum dengan kereta komuter. Parkir mobil dan motor tersedia di sekitar stasiun. Selain itu, area drop off juga disediakan untuk mobil, taksi dan angkot. Sedangkan area parkir off street untuk mobil dan motor yang tersedia di sekitar stasiun Tangerang kurang memadai, parkir bersifat tidak bertingkat sehingga area parkir tidak dapat memenuhi kebutuhan walaupun lahan yang dipakai mencapai 25 persen.

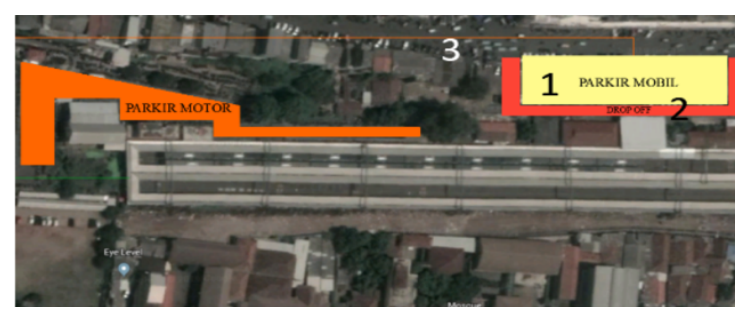

Gambar 7. Lahan parkir

Sumber: Hasil analisis, 2019

\section{Legibilitas dan Batasan}

Variasi fungsi dan ketinggian bangunan: Sebagian besar bangunan di sekitar stasiun Tangerang merupakan pertokoan dan hunian. Variasi ketinggian bangunan di sekitar stasiun memiliki tinggi rata-rata satu hingga tiga lantai. Sebagian besar bangunan digunakan sebagai toko dengan lebar bangunan kurang lebih empat sampai enam meter. Sedangkan ketinggian hunian yang berada di belakang pertokoan memiliki tinggi rata rata satu hingga dua lantai, dengan lebar empat sampai sepuluh meter.

1. Variasi ketinggian bangunan area pertokoan

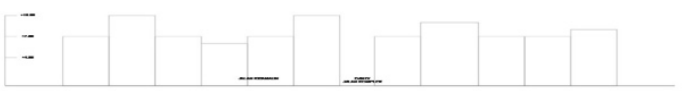

2. Variasi ketinggian bangunan area hunian

Gambar 8. Skyline dan tipologi bangunan pada kawasan hunian

Sumber: Hasil analisis, 2019

Permeabilitas, pusat aktivitas \& tata guna lahan: Pusat aktivitas pada kawasan ini tersebar pada area stasiun, area pertokoan sekitar stasiun dan area Pasar Lama.

Jalur pejalan kaki dan infrastruktur: Pada area ini kurang baik karena tidak adanya pedestrian yang layak, kurangnya lahan parkir, lebar pedestrian hanya 1.5-meter dan tidak adanya peneduhan alami dan peneduhan buatan yang kurang lebar, tidak seperti peneduh pada area pinggir Sungai Cisadane yang cukup area hijau.
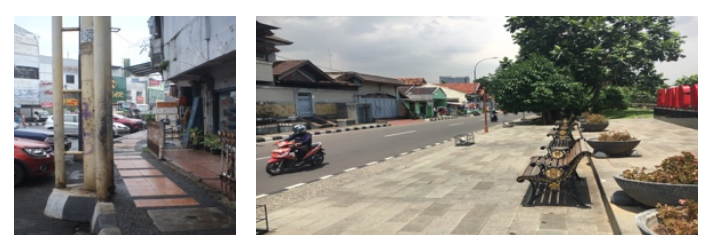

Gambar 9. Perbedaan kondisi pedestrian area stasiun dan area pinggir Sungai Cisadane Sumber: Dokumentasi pribadi, 2019

Proteksi air hujan dan panas: Proteksi air hujan dan panas hanya mengandalkan kantilever pertokoan yang lebarnya hanya 1-1.5 meter, sehingga jalur pedestrian masih tidak terlindungi dari hujan dan panas.

Penghawaan dan kenyamanan termal: Suhu rata rata pada daerah ini ada 28 derajat dimana kelembaban mencapai 77 persen 
sehingga suhu nyata yang dirasakan adalah 30 sampai 32 derajat di jalur pedestrian.

\section{Konsep Desain}

Setelah dilakukan analisis terhadap site stasiun Tangerang dan kriteria pengembangan TOD yang ada, perancangan ini akan didasari pada lima konsep pengembangan sesuai dengan kriteria pengembangan TOD yang nyaman terhadap pejalan kaki maupun pesepeda, berintegrasi dengan hunian yang berkepadatan tinggi dan memperhatikan perancangan yang berkelanjutan. Konsep konsep tersebut akan dijelaskan di bawah ini.

\section{Aksesibilitas, Konektivitas dan Sirkulasi}

Akses terbagi menjadi dua, yaitu akses pejalan kaki dengan sepeda dan akses kendaraan. Akses pejalan kaki dipermudah dengan cara memperbaiki dan menambah fasilitas jalur pedestrian dan diperlebar menjadi lebih dari empat meter. Akses sepeda dengan penyediaan jalur sepeda dengan minimal lebar dua meter. Selain itu, penyediaan pohon di sepanjang jalur pedestrian juga penting.

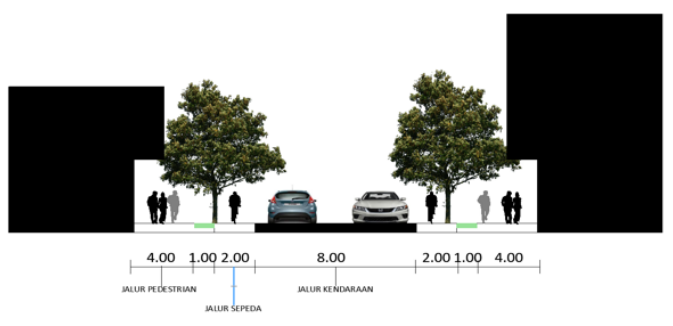

Gambar 10. Rencana pengembangan pedestrian Sumber: Hasil analisis, 2019

Penyediaan parkir sepeda di setiap titik pergantian moda transportasi seperti contohnya halte bus, stasiun kereta, ataupun drop off kendaraan pribadi (gambar 11). Dengan adanya parkir pesepeda ini akan memudahkan pesepeda untuk parkir dan berpindah ke moda transportasi lainnya.

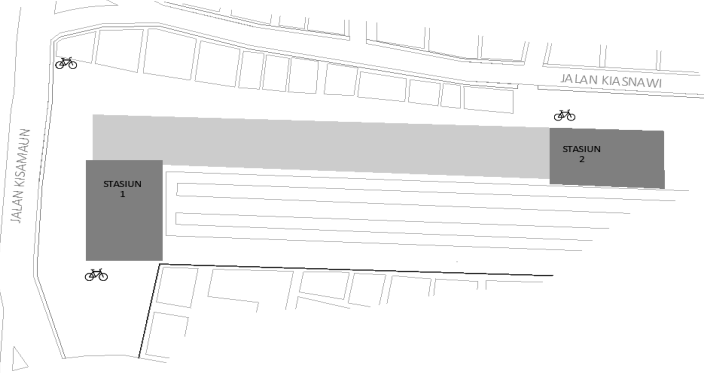

Gambar 11. Rencana pengembangan area parkir sepeda

Sumber: Hasil analisis, 2019

Sedangkan akses kendaraan dibuat di dua sisi, yaitu akses masuk Jalan Kisamaun dan akses masuk Jalan Kiasnawi, area stasiun yang terintegrasi dengan pedestrian, jalur pesepeda dan akses mobil, motor, akses barang seperti bongkar muat serta adanya drop off yang besar untuk angkutan umum lainnya seperti angkot dan taksi.

Akses pejalan kaki dibuat langsung dari statiun menuju ke Pasar Lama berupa jembatan sehingga bangunan kawasan Pasar Lama dan stasiun terhubung dan tidak terjadi kemacetan akibat pejalan kaki yang menyebrangi jalan. Jembatan akan memperbaiki konektivitas dan menghubungkan bangunan stasiun dengan bangunan lain di kawasan Pasar Lama dan memberikan jarak antara Pasar Lama setelah adanya jembatan adalah 250 meter (gambar 12).

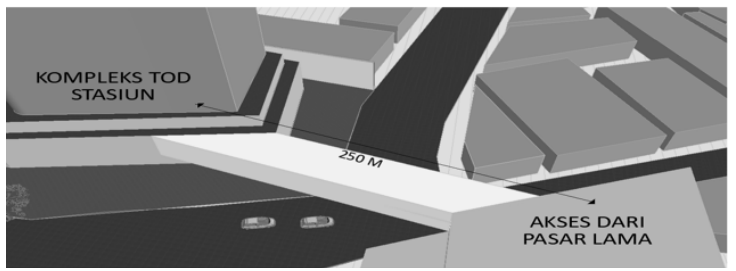

Gambar 12. Rencana jalur pedestrian dari kawasan Pasar Lama ke kompleks Sumber: Hasil analisis, 2019

Konektivitas ground area diperbaiki sehingga aktivitas di dalamnya semakin hidup dengan cara menyediakan tempat khusus untuk berjualan seperti ada titik titik khusus untuk pedagang kaki lima yang teratur dan tempat beraktivitas berupa taman yang memiliki fasilitas tempat 
duduk, pencahayaan dan tempat sampah yang memadai.

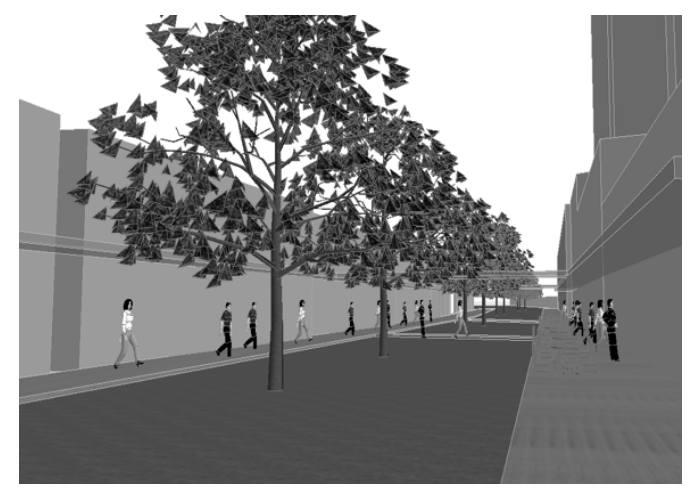

Gambar 13. Konektivitas dan suasana ground area

Sumber: Hasil analisis, 2019

\section{Keberagaman Pembagian Zona}

Keanekaragaman variasi aktivitas di dalam kompleks adalah berupa area pusat perbelanjaan (retail), hunian, ruang terbuka hijau, stasiun dan area parkir untuk keempat kegiatan tersebut.

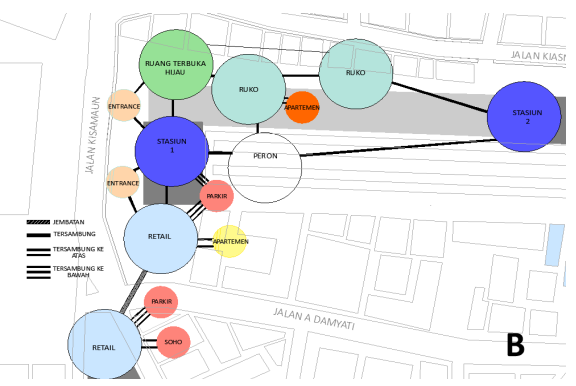

Gambar 14. Diagram bubble zoning Sumber: Hasil analisis, 2019

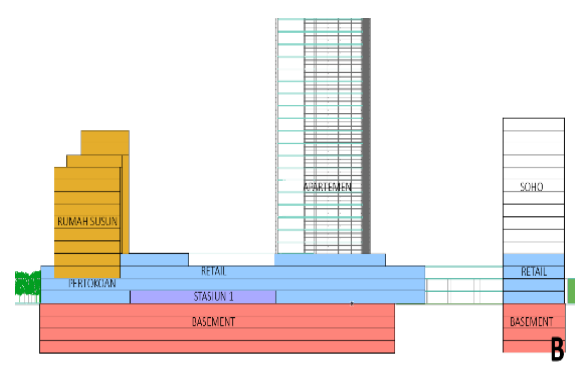

Gambar 15. Zoning

Sumber: Hasil analisis, 2019

Variasi hunian juga ditambah dengan menyediakan hunian bagi seluruh kalangan, terutama bagi kalangan Masyarakat Berpenghasilan Rendah (MBR) sebesar 20 persen dan manambahkan hunian campuran yang berupa campuran hunian dengan toko ataupun kantor.

Hunian yang akan dikembangkan dibagi menjadi:

Hunian konvensional berupa apartemen (hunian menengah) dan rumah susun sederhana (hunian sederhana). Terdapat dua jenis ukuran unit apartemen, yaitu 140unit berukuran 36-meter persegi dan 70unit berukuran 72-meter persegi. Terdapat dua jenis ukuran unit rumah susun sederhana, yaitu 60-unit berukuran 36meter persegi dan 60-unit berukuran 45meter persegi.

Hunian campuran berupa ruko (rumah toko) dan SOHO (small office home office). Unit ruko sebanyak 32-unit dengan ukuran 75-meter persegi per lantai dan unit $\mathrm{SOHO}$ sebanyak 108-unit dengan ukuran 72-meter persegi.

\section{Perpindahan Moda dan Parkir}

Adanya area drop off untuk kendaraan pribadi dan drop off khusus transportasi umum seperti angkot dan taksi.

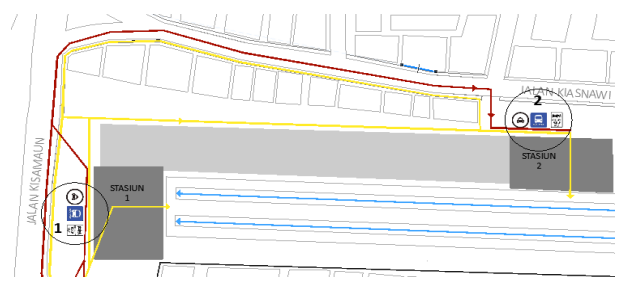

Gambar 16. Rencana area drop off Sumber: Hasil analisis, 2019

Parkir kendaraan pribadi yang tadinya berada di sekitar area pertokoan dipindah ke dalam parkir off street bawah tanah (basement) sehingga lahan parkir dapat terpakai secara efisien dan kemacetan menjadi berkurang.

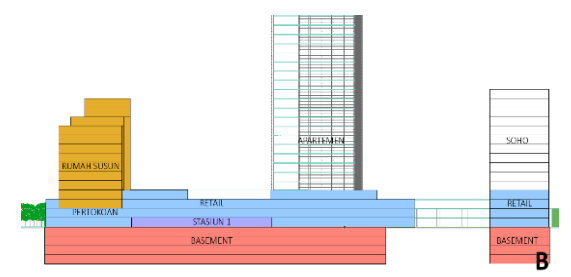

Gambar 17. Rencana area parkir bawah tanah (merah)

Sumber: Hasil analisis, 2019 
Berdasarkan tabel di atas, kebutuhan parkir dalam kompleks ini kurang lebih adalah 1000 kendaraan dan area parkir memiliki luas total antara 14.000 sampai 20.000meter persegi.

\section{Legibilitas, Tepian dan Kepadatan}

Pusat aktivitas akan digabung ke dalam satu bangunan di sekitar stasiun (mix use building). Bangunan dibuat dengan variasi ketinggian dan fungsi yang berbeda sehingga tercipta skyline daerah yang baik.

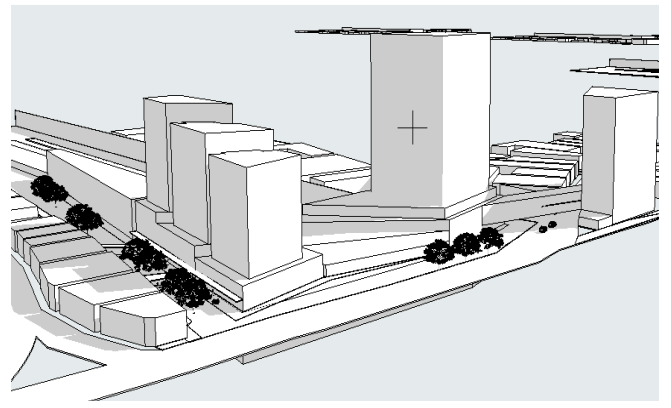

Gambar 18. Variasi ketinggian bangunan Sumber: Hasil analisis, 2019

Terdapat ketinggian bangunan yang variatif sebagai berikut:

Hunian berupa rumah susun dengan ketinggian 10 lantai dan apartemen yang berada dalam bangunan yang berbeda dengan SOHO dengan ketinggian 20 lantai. SOHO memiliki ketinggian 12 lantai. Ruko yang ada memiliki ketinggian dua dan tiga lantai, retail dan stasiun yang berada dalam satu bangunan yang sama memiliki ketingian 4 lantai. Sedangkan area parkir yang berada di bawah tanah memiliki kedalaman tiga lantai.

Transisi ketinggian bangunan juga penting diterapkan untuk menyesuaikan dengan keadaan sekitar karena bangunan di sekitar kompleks hanya memiliki ketinggian satu sampai empat lantai. Selain itu, keseluruhan bangunan tinggi dibuat menghadap ke kawasan Pasar Lama sehingga aktivitas dan pemandangan Pasar Lama dapat terlihat.

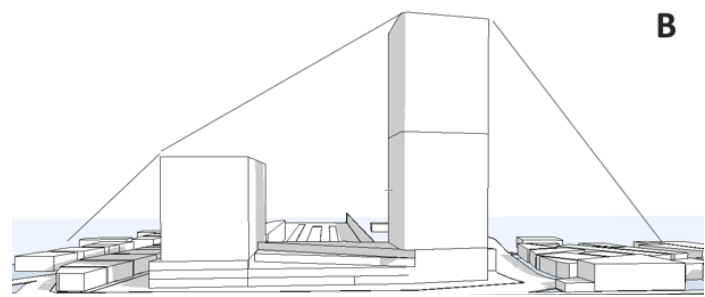

Gambar 19. Transisi ketinggian bangunan Sumber: Hasil analisis, 2019

Bentuk bangunan didapat dari pola site yang berbentuk kotak-kotak yang tidak beraturan di sekitar stasiun, namun semakin dekat dengan perlintasan kereta, bangunan yang ada semakin tertata. Bentuk bangunan yang dirancang merupakan transformasi bentuk persegi yang dibuat maju mundur di bagian atas, selain mempertimbangkan arah matahari, juga memberikan pemandangan ke area sekitar yang lebih baik.

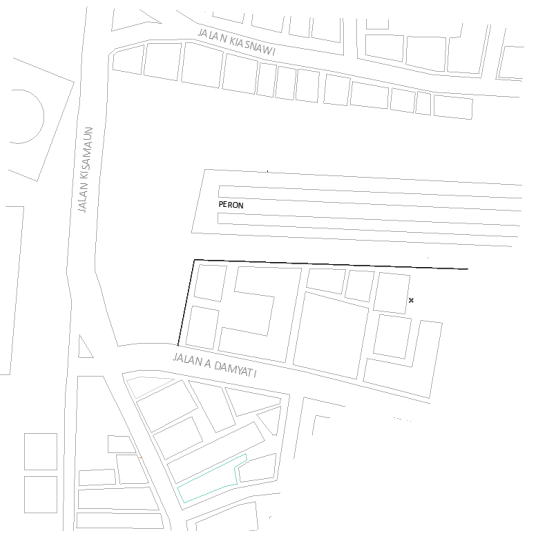

Gambar 20. Transformasi pola bentuk bangunan pada kawasan Pasar Lama Sumber: Hasil analisis, 2019

Selain itu, pada bagian atas bangunan juga terdapat perbedaan level dengan mengupayakkan area ruang terbuka seperti panggung yang langsung menghadap ke Pasar Lama dan Sungai Cisadane. Ketinggian ruang terbuka ini setinggi 20 lantai bangunan agar pemandangan Pasar Lama dan Sungai Cisadane dapat terlihat. 


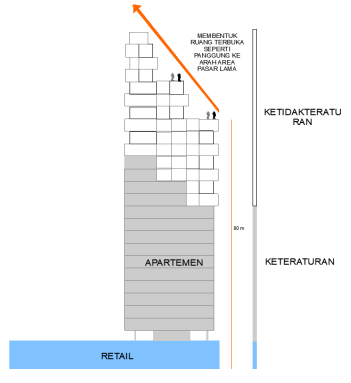

MAMSANA PASAR L LAMI

Gambar 21. Transformasi pola bentuk rancangan bangunan

Sumber: Hasil analisis, 2019

Bentuk bangunan juga diambil berdasarkan bangunan hunian yang berada di kawasan Pasar Lama yang sebagian besar mengalami perkembangan dan pembesaran ukuran disebabkan hunian digunakan juga menjadi pertokoan.
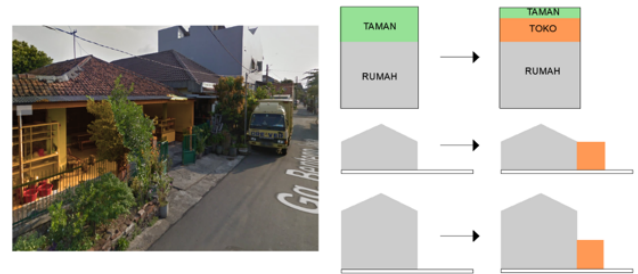

Gambar 22. Bentuk dan perkembangan hunian kawasan Pasar Lama

Sumber: www.earth.google.com, diolah peneliti

Dengan mempertimbangkan hal ini, maka unit apartemen didesain dengan modulmodul yang diperbesar sehingga memberikan kesan menonjol jika dilihat dari luar. Tonjolan ini dibuat sebagai balkon dan penghalang sinar matahari (sunshade)

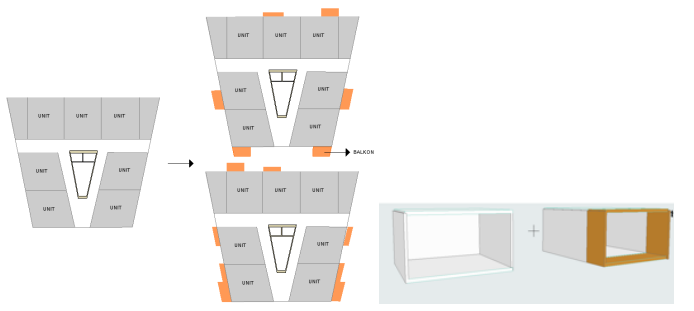

Gambar 23. Bentuk rancangan unit apartemen Sumber: Hasil analisis, 2019

Batasan antar bangunan dibuat terbuka, sehingga ada konektivitas antar bangunan, penghapusan pagar antar bangunan sehingga terlihat semakin luas.

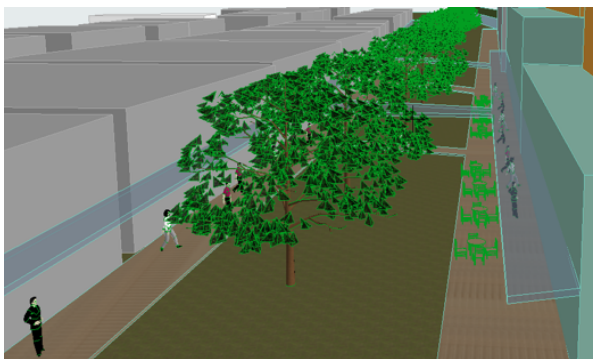

Gambar 24. Batasan bangunan (merah) berupa ruang terbuka

Sumber: Hasil analisis, 2019

Tata guna lahan dirancang seefisien mungkin agar kepadatan semakin tinggi (target kepadatan hunian adalah 400 orang per hektare) dan luas RTH direkomendasikan sebanyak 30 persen dari luas lahan atau setidaknya 5 persen dari total luas bangunan.

Kompleks bangunan terbagi atas program ruang utama berupa hunian dengan luas mencangkup 42 persen dari total luas bangunan, retail mencangkup 31 persen, area stasiun mencangkup tiga persen, ruang terbuka hijau sebesar 7 persen dari total luas bangunan dan parkir kendaraan sebesar 17 persen.

\section{Ruang Terbuka Hijau, Kenyamanan dan Desain Pasif}

Fasilitas penunjang aktivitas sosial dapat dikembangkan berupa ruang terbuka hijau, pepohonan yang rindang, area jogging, tempat bermain anak-anak atau tempat duduk yang mendukung adanya kegiatan sosial. Fasilitas ini dapat disebar pada beberapa titik area.
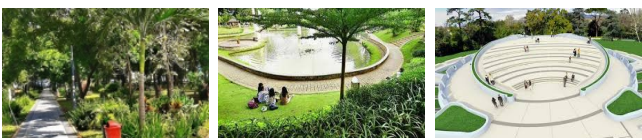

Gambar 25. Area penunjang kegiatan sosial Sumber: www.image.google.com

Ruang terbuka hijau yang terdapat pada kompleks TOD ini berupa:

a) Skygarden atau taman vertikal yang berada di atas retail, bangunan $\mathrm{SOHO}$ dan apartemen dan di atas jembatan penyebrangan.

b) Roof garden atau taman atap yang berada di atas bangunan SOHO dan 
apartemen yang ditujukan sebagai fasilitas bagi apartemen.

c) Ruang terbuka hijau yang mengelilingi area batasan bangunan untuk menghidupkan ground area kawasan pertokoan.

Adanya peneduhan buatan berupa kanopi atau kantilever bangunan dapat mempengaruhi kenyamanan termal untuk pejalan kaki. Selain itu, pepohonan yang rindang juga mempengaruhi kenyamanan termal dan kualitas udara. Dalam pengembangan TOD aspek desain pasif menjadi hal yang perlu dipertimbangkan. Desain pasif dapat berupa penggunaan energi terbarukan, ataupun perencanaan bangunan berdasarkan arah sinar matahari dan angin. Desain pasif tersebut berupa:

1) Arah matahari dimana bangunan yang menghadap ke arah barat dibuatkan penghalang sinar matahari sehingga bagian bangunan yang menghadap ke arah barat tidak terlau panas.

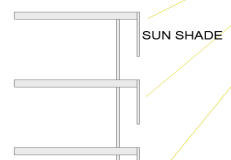

Gambar 26. Sun shade pada sisi bangunan yang menghadap barat

Sumber: Hasil analisis, 2019

2) Arah angin yang menuju dari utara ke selatan. Angin dapat dipakai sebagai penghawaan alami sehingga dapat mengurangi penghawaan buatan seperti AC atau kipas angina dengan implementasi cross ventilation.
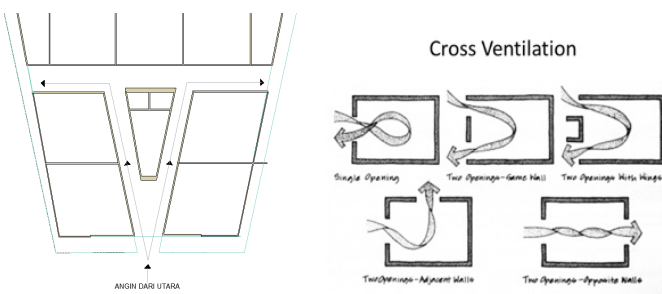

Gambar 27. Implementasi penggunaan sirkulasi udara alami

Sumber: Hasil analisis, 2019 dan image.google.com/crossventelation
3) Penggunaan sinar matahari dengan cara di beberapa titik bangunan dibuat terbuka sehingga sinar matahari dapat masuk ke dalam bangunan dan sinar matahari menjadi pencahayaan alami.

4) Pengolahan air hujan, dimana air hujan dikumpulkan, ditampung, dan dibersihkan untuk digunakan lagi sebagai air bersih untuk mencuci maupun MCK.

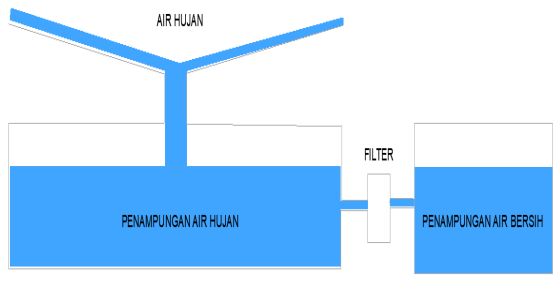

Gambar 28. Pengoahan air hujan menjadi air bersih

Sumber: Hasil analisis, 2019

\section{Hasil Perancangan berdasarkan Konsep Desain}

Hasil perancangan pada sub bab ini dibuat berdasarkan evaluasi konsep desain yang sudah dibahas di sub bab sebelumnya.

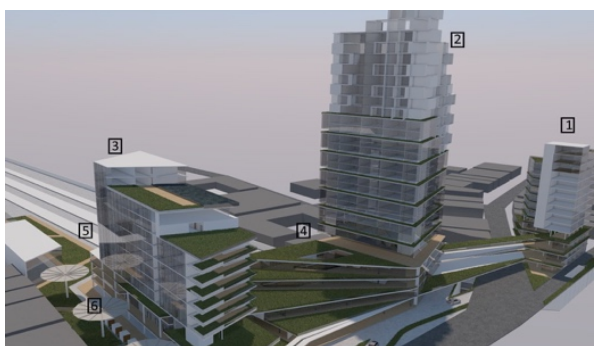

Gambar 29. Suasana aerial kompleks TOD Sumber: Hasil analisis, 2019

Kompleks TOD ini terdiri dari:

1) Bangunan SOHO 14 lantai yang memiliki 32-unit SOHO dan terintegrasi dengan area retail di bawahnya.

2) Apartemen 20 lantai yang berada di bangunan utama, terdiri atas 108-unit dan terintegrasi langsung dengan area retail di bawahnya.

3) Rumah susun sederhana 10 lantai yang berada di atas pertokoan. 
4) Retail yang berada di bawah apartemen dan persis di atas stasiun kereta.

5) Pertokoan yang berada di bawah rumah susun sederhana.

6) Ruang Terbuka hijau yang berada di pinggir bangunan.

Bangunan SOHO berada persis di sebelah kawasan Pasar Lama. Bangunan ini merupakan pintu masuk dari kawasan Pasar Lama menuju ke kompleks utama.

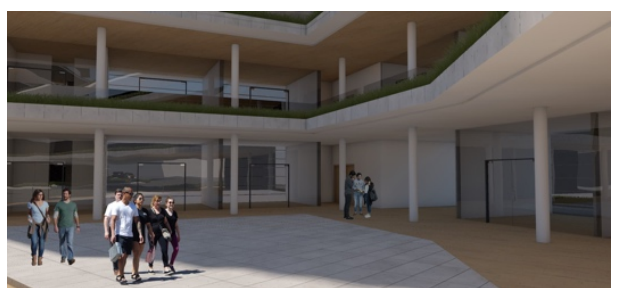

Gambar 30. Suasana retail di bawah bangunan SOHO

Sumber: Hasil analisis, 2019

Lantai satu sampai dengan tiga digunakan sebagai area retail yang dikhususkan untuk berjualan minuman dan makanan. Pada bagian tengah terdapat area khusus yang digunakan untuk berbagai acara seperti acara kesenian, acara musik, ataupun digunakan sebagai tempat senam di hari libur.

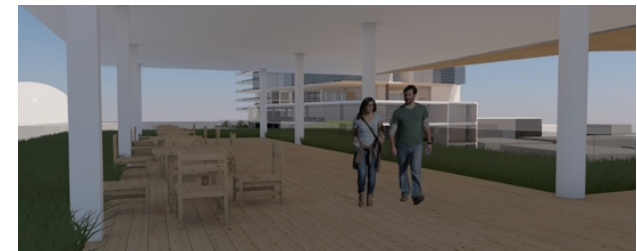

Gambar 31. Ruang transisi antara unit SOHO dengan retail

Sumber: Hasil analisis, 2019

Sedangkan lantai empat digunakan sebagai tempat transisi antara $\mathrm{SOHO}$ dengan retail. Tempat transisi ini difungsikan sebagai lobby dan ruang duduk bagi penghuni unit $\mathrm{SOHO}$

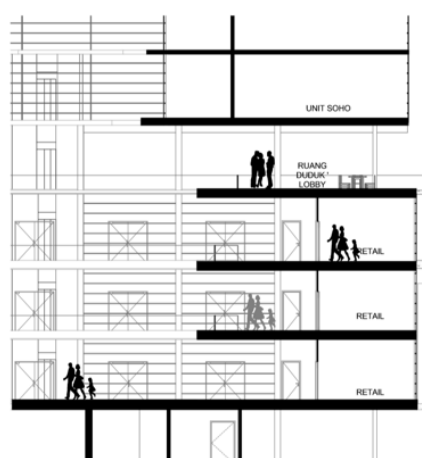

Gambar 32. Potongan bangunan SOHO Sumber: Hasil analisis, 2019

Setiap lantai pada bangunan ini terdiri atas empat unit SOHO dengan tiga unit berukuran 72-meter persegi dan satu unit berukuran 48-meter persegi.

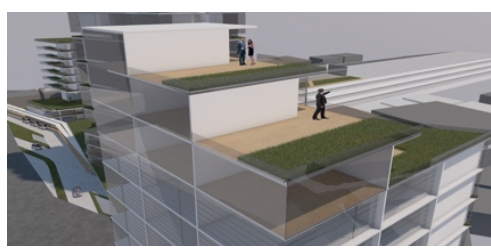

Gambar 33. Ruang terbuka di atas bangunan SOHO

Sumber: Hasil analisis, 2019

Pada bagian paling atas bangunan $\mathrm{SOHO}$, terdapat ruang terbuka seperti panggung yang memiliki pemandangan ke area Pasar Lama dan Sungai Cisadane. Bangunan apartemen yang memiliki ketinggian 20 lantai dan terhubung langsung dengan retail di bawahnya. Sama seperti bangunan SOHO, pada bagian atas bangunan ini terdapat ruang terbuka yang menghadap ke area Pasar Lama dan Sungai Cisadane.

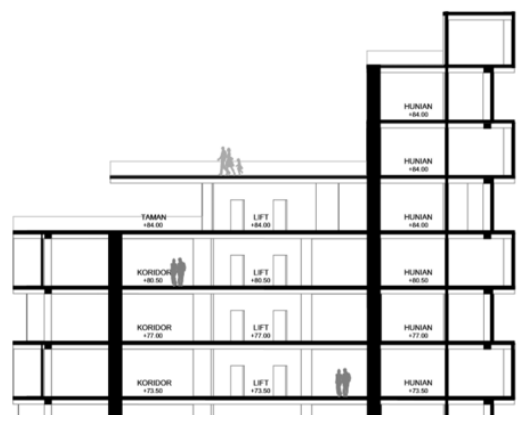

Gambar 34. Potongan bangunan apartemen yang menujukkan adanya area ruang terbuka pada atap bangunan

Sumber: Hasil analisis, 2019 
Bangunan apartemen dimulai dari lantai lima sampai 25 dimana lobby apartemen sebagai transisi antara area retail dan hunian terdapat pada lantai lima. Tiap lantai apartemen terdiri atas tujuh unit apartemen dengan ukuran 72-meter persegi atau 14-unit apartemen dengan ukuran 36meter persegi.

Rumah susun sederhana dengan ketinggian 10 lantai yang terdiri atas 120 unit. Keunikan pada rumah susun ini adalah tersedianya berbagai titik untuk beraktivitas sosial, seperti taman pada setiap lantai dan ruang duduk pada setiap lantai. Selain itu, pada lantai atas terdapat fasilitas seperti kolam renang dan fasilitas kebugaran lain yang dapat diakses oleh penghuni di bagian atas bangunan.
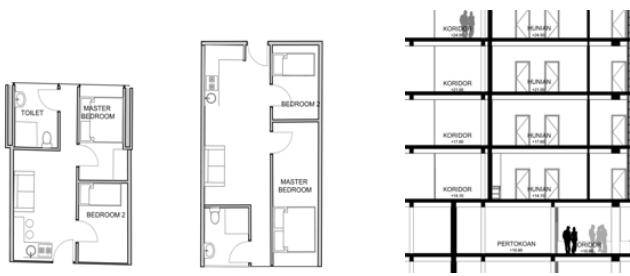

Gambar 35. Denah unit a dan b, potongan rumah susun dengan pertokoan Sumber: Hasil analisis, 2019

Rumah susun ini terdiri dari dua jenis unit hunian yaitu unit a yang berukuran 36meter persegi dan unit $b$ dengan ukuran 45meter persegi. Rumah susun ini juga terhubung langsung dengan pertokoan di bawahnya.

Retail yang terletak di bawah apartemen, terdiri atas pertokoan yang juga langsung terhubung langsung ke stasiun kereta komuter di bawahnya.
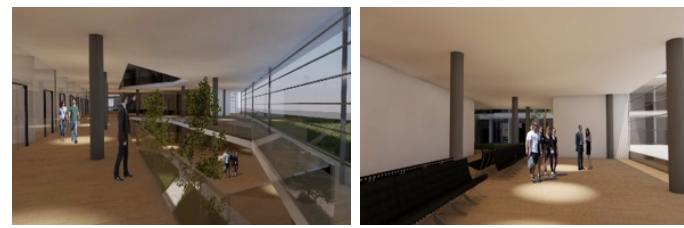

Gambar 36. Suasana dalam area retail dan area tunggu stasiun

Sumber: Hasil analisis, 2019

Pada area ini, terdapat juga pencahayaan alami berupa skylight sehingga meminimalkan penggunaan lampu di siang hari. Area retail terdiri dari empat lantai dimana lantai satu merupakan stasiun dengan retail berupa minimart dan kios makanan. Sedangkan lantai dua hingga empat digunakan semuanya sebagai ruang retail. Terdapat juga drop off khusus yang dibagi tiga yaitu drop off angkot, taksi dan kendaran pribadi.

Pertokoan empat lantai yang berada di ujung bangunan terhubung dengan ruang terbuka hijau secara langsung. Pertokoan ini berada persis di bawah rumah susun sederhana. Pertokoan ini dibuat khusus untuk menjual barang barang kebutuhan penghuni rumah susun sederhana.
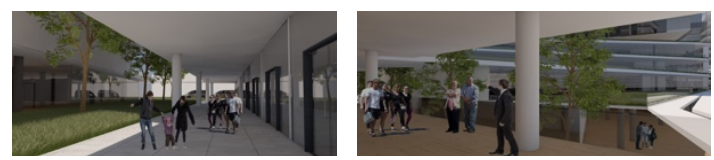

Gambar 37. Suasana retail lantai satu dan dua dalam stasiun

Sumber: Hasil analisis, 2019

Pertokoan ini dibuat terbuka dan menggunakan ventilasi dan penghawaan alami. Selain itu, di sisi pinggir pertokoan terdapat taman yang cukup besar sebagai pengontrol suhu dalam ruangan. Ruang terbuka hijau berfungsi sebagai ruang sosial, ruang bersantai dan ruang untuk pedagang kaki lima. Pedagang kaki lima diberikan tempat khusus pada area ini untuk berjualan sehingga area dapat tetap tertata rapi.

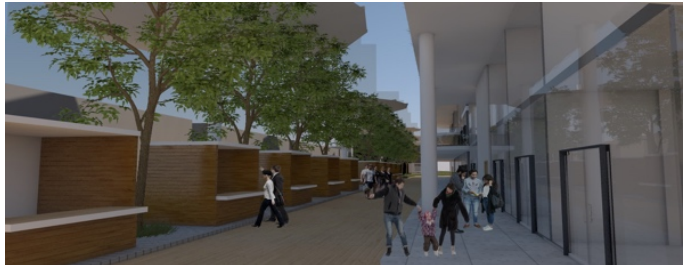

Gambar 38. Suasana ground level berupa pertokoan yang menghadap ke pedagang kaki lima yang tertata

Sumber: Hasil analisis, 2019

Pada ruang terbuka ini juga terdapat kanopi yang berfungsi sebagai peneduhan dan sekaligus sebagai penyimpanan air hujan. 


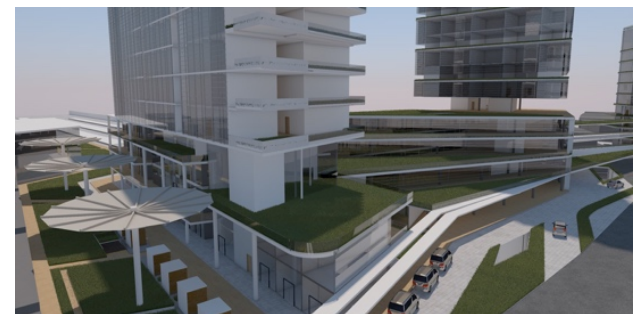

Gambar 39. Kanopi pada area ruang terbuka hijau

Sumber: Hasil analisis, 2019

\section{Kesimpulan}

Rancangan hunian dengan TOD ini dilakukan berdasarkan kriteria-kriteria yang sudah dibuat berdasarkan teori-teori yang dipilih sehingga diharapkan dengan adanya pengembangan kompleks ini, permasalahan yang ada di area stasiun Pasar Lama dapat teratasi. Tidak hanya dari segi program dan bentuk, tetapi pengelolaan yang baik pada kawasan TOD juga merupakan hal yang penting bagi berjalannya kegiatan dan aktivitas pemakainya. Dengan demikian, kawasan TOD dapat memberikan dampak positif bagi lingkungan sekitarnya.

\section{Ucapan Terima Kasih}

Terimakasih kepada pihak LPPM UPH yang telah mendanai penelitian internal Tugas Akhir dengan No. Penelitian P-084SoD/III/2019, dengan kontrak penelitian No: 120/LPPM-UPH/III/2019.

\section{Daftar Pustaka}

Calthorpe, P. (1993). The next American metropolis: Ecology, community, and the American dream. New York: Princeton Architectural Press.

Cho, Im. S. (2016). Reframing urban space. New York: Routledge, Taylor \& Francis Group.

Institute for Transportation and Development Policy. (1993). Sustainable transport. New York: ITDP.

Porter, D. (2002). Making smart growth work. Washington: Urban Land Institute. 